\title{
Research on Foreign Trade of Guangdong Province Based on the Emergy Ecological Footprint
}

\author{
YU-XIA DU ${ }^{1}$,MING-JIE LI ${ }^{1,2^{*}}$,TSUNG-XIAN LIN ${ }^{1}$ \\ 1. Department of Economics and Finance, Huashang College Guangdong University \\ of Finance \& Economics, Guangzhou, Guangdong, CHINA \\ 2. School of economics, Central South University of Forestry and Technology, \\ Changsha, Hunan, CHINA
}

\begin{abstract}
In order to understand whether Guangdong's foreign trade is coordinated with ecological environment, we use the emergy ecological footprint model to analyze the current status of emergy ecological footprint of Guangdong's foreign trade which is divided into biological resource account, energy account, and industrial products account from the year 2008 to 2018. The results show the trade of biological resources account and energy account are ecological reserve and the trade of industrial products is ecological deficit, which means the trade is coordinated with ecological environment in biological resources account and energy account and is not coordinated with ecological environment in industrial products accounts. We also propose that the coordinated development of Guangdong's foreign trade and the ecological environment needs to focus on the protection of cropland, grazing land, forest land, fishing ground, the improvement of energy efficiency, increasing investment in high-tech research and development, strengthen the pollution control and other aspects.
\end{abstract}

Keywords: emergy; ecological footprint; foreign trade; Guangdong Province

Received: May 22, 2020. Revised: October 2, 2020. Accepted: October 10, 2020. Published: October 17, 2020.

\section{Introduction}

Upholding the harmonious coexistence of human beings and nature and building an ecological civilization are long-term plans for the sustainable development of the Chinese nation. Economic development should keep pace with the development of the ecological environment, and the development of foreign trade should also take into account both economic interests and ecological interests. In recent years, Guangdong Province's total foreign trade has accounted for about $25 \%$ of the country's total foreign trade, with a trade surplus of RMB13842.39 billion in 2018. While trade brings great economic benefits, it also faces pressure from the domestic ecological environment. This paper adopted the emergy analysis method to divide the foreign trade of Guangdong Province from 2008 to 2018 into biological resources account, energy account, and industrial products account. It studied the ecological footprint of import and export trade and judged whether the economic benefits of foreign trade in Guangdong Province were coordinated with its ecological benefits. It will provide direction for Guangdong Province to coordinate the economic and ecological benefits of foreign trade in the future, and to shift foreign trade to high-quality development. Guangdong province as a province with a high level of economic development in China, its ecological environment protection, economic development, and market system reform play important roles in the social, economic, and ecological development of other regions in China even in other countries and regions. Therefore, it is of great theoretical and practical significance to study the coordinated development of foreign trade and the ecological environment in Guangdong Province. 


\section{Research Area and Method}

\subsection{Overview of the research area}

Located in the southernmost part of mainland China, Guangdong Province borders Fujian Province, Jiangxi Province, Hunan Province, and Guangxi Zhuang Autonomous Region. It is also adjacent to Hong Kong, Macao, and Hainan. With a total land area of 17,972,500 hectares, it accounts for $1.87 \%$ of the national land area. Its coastline is $4,114 \mathrm{~km}$ long, ranking first in the country. Guangdong Province is rich in water resources, with 614 main rivers and tributaries that have a combined watershed area exceeding 100 square kilometers. Located at the junction of the Asia-Europe plate and the Pacific plate, 148 mineral resources have been discovered, with 101 kinds of mineral resources and 1,932 kinds of mineral resources proven. Due to its abundant light, heat, and water resources, it is home to various rare animals, plants, and cash crops.

In 2018, the GDP of Guangdong Province was RMB 9,7277.77 billion, accounting for $10.64 \%$ of the total GDP of the country. It is a major economic province and is mainly engaged in manufacturing and tertiary industries. In terms of trade, Guangdong Province's foreign trade has accounted for about $25 \%$ of the country's foreign trade in recent years. With general trade as the main mode, it processes imported materials and accepts customers' materials for processing. Its foreign trade has been in a surplus state. From an economic point of view, foreign trade has brought great contributions to Guangdong Province's economic development. The foreign trade status of Guangdong Province in recent years is shown in Table 1.

Table 1. Foreign Trade Status of Guangdong Province in Recent Years (Unit: RMB 100 million)

\begin{tabular}{cccccc}
\multicolumn{7}{c}{ Recent Years (Unit: RMB 100 million) } \\
\hline & $\begin{array}{c}\text { Exports } \\
\text { of } \\
\text { Guangdo } \\
\text { ng } \\
\text { Province }\end{array}$ & $\begin{array}{c}\text { Imports } \\
\text { of } \\
\text { Guangdo } \\
\text { ng } \\
\text { Province } \\
\text { and } \\
\text { Export } \\
\text { of } \\
\text { Guangdo } \\
\text { ng } \\
\text { Province }\end{array}$ & $\begin{array}{c}\text { Amount of } \\
\text { national } \\
\text { import and } \\
\text { export trade }\end{array}$ & $\begin{array}{c}\text { Proportio } \\
\text { n in the } \\
\text { country }\end{array}$ \\
\hline 2008 & 28071.26 & 19397.94 & 47469.2 & 179921.5 & $26.38 \%$ \\
\hline 2009 & 24520.36 & 17225.28 & 41745.64 & 150648.1 & $27.71 \%$ \\
\hline 2010 & 30678.78 & 22454.77 & 53133.56 & 201722.3 & $26.34 \%$ \\
\hline 2011 & 34347.45 & 24642.95 & 58990.41 & 236402 & $24.95 \%$ \\
\hline 2012 & 36237.37 & 25874.12 & 62111.49 & 244160.2 & $25.44 \%$ \\
\hline 2013 & 39414.05 & 28209.4 & 67623.46 & 258168.9 & $26.19 \%$ \\
\hline 2014 & 39693.38 & 26443.9 & 66137.28 & 264241.8 & $25.03 \%$ \\
\hline 2015 & 39983.1 & 23576.6 & 63559.7 & 245502.9 & $25.89 \%$ \\
\hline 2016 & 39520.54 & 23579.14 & 63099.68 & 243386.5 & $25.93 \%$ \\
\hline 2017 & 42192.86 & 25976 & 68168.86 & 278099.2 & $24.51 \%$ \\
\hline 2018 & 42744.06 & 28901.67 & 71645.73 & 305010.09 & $23.49 \%$ \\
\hline & & & & & \\
\hline
\end{tabular}

\subsection{Research method}

The concept of ecological footprint was first put forward by Rees [1] and was followed by a complete ecological footprint model developed by Wackernagel[2]. Odum combined the principles of ecosystem, ecological emergy, and ecological economy to form a systematic emergy theory and analysis method[3].

Ecological footprint has been widely used in research on the sustainable development of trade and environment. Hubacek et al. (2003) used the input-output model to analyze the ecological footprint of 15 countries in the European Union and other countries at that time[4]. Daniel et al. (2008) adopted the PLUM model to calculate the ecological footprint material flow of international trade[5]. Lei et al. (2009) analyzed whether the ecological footprint trade of Macao's population could meet the requirements of sustainable development by using the ecological footprint model[6]. Lazarus (2015) analyzed the relationship between the ecological footprint of trade and biodiversity loss[7]. Celil et al (2019) investigated the nonlinear effects of economic growth on ecological footprints as an indicator of environmental degradation by using the data of 26 EU countries from 1993-2013[19]. Veli Yilanc et al. (2018) analyzed the stability of the ecological footprint of OECD 25 countries from 1996 to 2013, and inferred the impact of policy formulation on the ecological footprint [20]. Alola et al. (2019) employed the PMG-ARDL model to analyze the equilibrium relationship among the EU's ecological footprint, real GDP, trade openness, fertility rate, renewable energy, and non-renewable energy consumption[21]. Sajid Ali et al(2020) addressed the dynamic common correlated effects of trade openness, FDI, and institutional performance on environmental quality in OIC countries[22]. In China, scholars have focused more on emergy theory and the ecological footprint of emergy improvement. Lan(1995) used emergy theory to analyze the emergy of agricultural eco-economic systems and applied it to the evaluation of sustainable development of an ecosystem[12]. Zhao et al. (2009)[13], Cao et al. (2018)[14], Feng et al. (2018) [15], and Li et al. (2018)[16] widely applied emergy ecological footprint theory to the evaluation of the sustainable development of regional ecological economies. Chen et al. (2005) studied the 
ecological footprint of China's foreign trade[17].Yu et al (2010) used emergy analysis to calculates the emergy transfer of China's import and export trade, and used a series of comprehensive emergy indices to comparatively analyze China's ecological elements transfer and ecological benefits during the import and export trade with major trading partners[18]. Lu et al. (2013) calculated the ecological footprint of China's international trade connotation from 1991 to 2010 using the emergy theory model and proposed relevant countermeasures to improve China's ecological terms of trade and promote the sustainable development of foreign trade[8]. Li et al. (2013) used the IOPLUM model to analyze the ecological footprint of natural capital in China's import and export trade in 2013[9]. Some relevant studies can be found in [23].

Among the methods of analyzing the ecological footprint and sustainable development of trade, this paper selected the emergy ecological footprint method to analyze the ecological footprint occupied by the biological resources account and energy account in the foreign trade of Guangdong Province and analyze the emergy ecological footprint occupied by energy consumption in the industrial products account of foreign trade based on the input-output table. The emergy conversion rate, emergy density and other parameters used in the emergy ecological footprint model are more stable than a single ecological footprint analysis. The emergy conversion rate can reflect the level of energy and matter in the ecosystem; combined with the ecological footprint model, the emergy ecological footprint method project analysis is relatively complete, it also can better reflect the difference in ecological resources occupied by different products and the sustainable development of the industry, and it is more comprehensive and systematic in measuring the ecological benefits of foreign trade. Therefore, this paper will use the emergy ecological footprint method to measure the ecological footprint of foreign trade, and conduct an empirical analysis of whether the trade and ecological environment of Guangdong Province are coordinated.

\section{Model and Data}

\subsection{Ecological footprint model based on emergy improvement}

(1) Emergy ecological footprint of the biological resources account

$$
\mathrm{EF}_{i}=\sum \mathrm{C}_{i} E_{i} T_{i} / P
$$

where, $C_{i}$ is the consumption of the $i$-th commodity, $E_{i}$ is the energy conversion coefficient of the $i$-th commodity, $T_{i}$ is the emergy conversion rate of the $i$-th commodity, and $\mathrm{P}$ is the global or regional emergy density.

The calculation formula of commercial solar emergy is commodity quantity (ton) * corresponding energy conversion coefficient (joule/ton) * corresponding emergy conversion rate (solar joule/joule).

According to the ecological footprint theory based on emergy improvement, the solar emergy of various natural resource products in the foreign trade of Guangdong Province was divided by the emergy density to obtain the ecological footprint of the productive land occupied by various foreign trade products, i.e., cropland, forest land, grazing land, fishing ground, fossil energy land, and construction land.

The bioproductive land area $\left(\mathrm{hm}^{2}\right)=$ emergy (sej)/emergy density (sej/hm ${ }^{2}$ ) of the import and export commodities[10].

(2) Emergy ecological footprint of the energy account

The emergy ecological footprint of imported and exported energy was calculated in the same way as the emergy ecological footprint of the biological resources account and is therefore repeated here.

(3) Emergy ecological footprint of the industrial products account

For industrial products in import and export trade, the energy consumed in the production process was mainly considered, and the energy consumption coefficient of various industries was calculated in combination with the input-output table, so as to understand the energy consumption in the import and export industrial products account.

Firstly, according to the Industrial Classification for National Economic Activities-2017, import and export industrial products were divided into different industries, and the energy consumption coefficients of different industries were then respectively calculated.

Direct energy consumption coefficient: $\mathrm{D}_{\mathrm{j}}=$ $\mathrm{N}_{\mathrm{j}} / \mathrm{V}_{\mathrm{j}}$ 
where $\mathrm{N}_{\mathrm{j}}$ is the total energy consumption of industry $\mathrm{j}$ and $\mathrm{V}_{\mathrm{j}}$ is the total output value of industry $\mathrm{j}$.

Indirect energy consumption coefficient: $\mathrm{I}_{\mathrm{j}}=$ $\Sigma \mathrm{D}_{\mathrm{i}} \mathrm{b}_{\mathrm{ij}}$ (i refers to the number of industries to which import and export trade products belong)

where $D_{i}$ is the direct energy consumption coefficient of industry $i$ and $B_{i j}$ is the complete consumption coefficient in the input-output table.

Complete energy consumption coefficient: $T_{j}$ $=\mathrm{D}_{\mathrm{j}}+\mathrm{I}_{\mathrm{j}}$

The energy consumption value of import and export industrial products $=$ import and export trade volume * complete energy consumption coefficient.

The emergy ecological footprint of import and export industrial products = energy consumption value of import and export industrial products (standard coal) $* 7000000$ $(\mathrm{kcal} / \mathrm{tce}) * 4185.85(\mathrm{~J} / \mathrm{kcal}) /$ global average emergy footprint of energy $\left(\mathrm{J} / \mathrm{ghm}^{2}\right)[11]$.

(4) Sustainable status of foreign trade of Guangdong Province based on the emergy ecological footprint

After calculating the respective ecological footprints occupied by the import and export commodities, the ecological footprint of the import commodities was subtracted from the ecological footprint of the export commodities, and the difference was positive. This result indicated that the ecological footprint input through foreign trade was greater than the ecological footprint output, and that foreign trade had an ecological surplus. In this case, foreign trade was in a surplus mode, both from the perspective of economic benefits and ecological benefits, and that trade was in a state of sustainable development.

A negative difference would indicate that the ecological footprint output through foreign trade was greater than the input. In this case, the economic benefits of foreign trade would be in a surplus state; however, the ecological benefits of foreign trade are in the net output, which is not conducive to the coordinated development of foreign trade and ecological environment. In this regard, trade is in an unsustainable state of development.

\subsection{Data selection}

The foreign trade data of Guangdong Province were derived from the Guangdong Statistical Yearbook published from 2009 to 2019. The energy consumption and total output value of the industrial industry came from the Guangdong Statistical Yearbook of Industry published from 2009 to 2019. The data on the energy conversion coefficient and emergy conversion rate came from Lan's Emergy Analysis of Eco-economic System and the National Environmental Accounting Database (NEAD) from the University of Florida's Center for Environmental Policy. The emergy density data came from Living Planet Report 2016. The global average emergy ecological footprint of energy was 71 $\mathrm{GJ} / \mathrm{hm}^{2}$.

\section{Analysis of Results}

\subsection{Biological resources account}

Guangdong Province's export biological resources account mainly includes agricultural products (grains, vegetables, fresh and dried fruits, edible oil, tea, medicinal materials, paper cigarettes, raw silk, etc.), livestock products (live pigs, live poultry, fresh and frozen pork, canned pork, etc.), and aquatic products (live fish and fresh frozen prawns). Under the export biological resources account, the ecologically productive land area includes cropland, forest land, grazing land, and fishing ground. The analysis found that in the export trade biological resources account of Guangdong Province, grazing land occupied the most ecologically productive land area, followed by Fishing grounds, while cropland occupied the least ecologically productive land area. The emergy ecological footprint of the biological resources accounts for specific export commodities is shown in Figure 1.

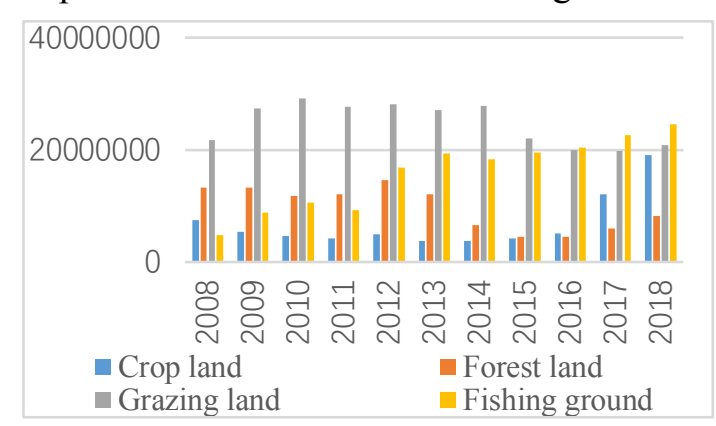

Figure 1. Emergy Ecological Footprint of the Export Biological Resources Account (Unit: ghm2)

Guangdong Province's imported biological resources account mainly includes cereals, soybeans, fresh and dried fruits, edible vegetable oil, sugar, feed, paper cigarettes, rubber, logs, sawn timber, pulp, wool, raw cotton, and other products. The occupied 
ecologically productive land includes crop land, forest land, and grazing land. In the imported biological resources account, crop land occupied the most ecologically productive land, followed by forest land, while grazing land occupied the least ecologically productive land area. The emergy ecological footprint of the biological resources account for imported commodities is shown in Figure 2.

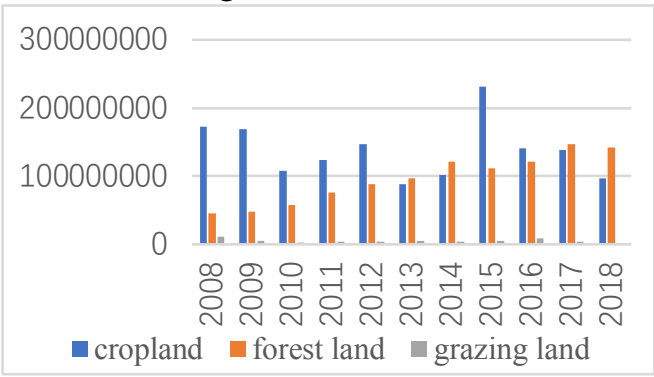

Figure 2. Emergy Ecological Footprint of the Imported Biological Resources Account (Unit: ghm2)

\subsection{Energy account}

As Guangdong Province's energy exports are mainly refined oil, only one item of cost oil was included in the foreign trade energy export account. The type of ecologically productive occupied land was fossil energy land. The details are shown in Figure 3.

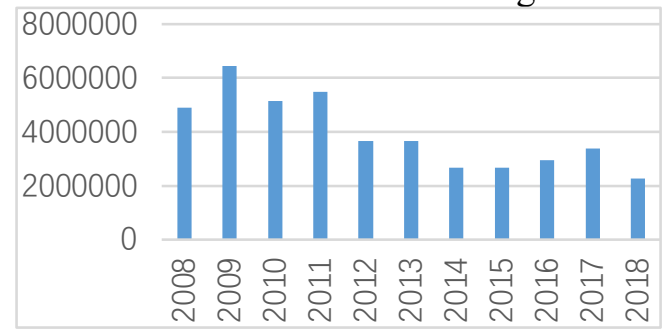

Figure 3. Emergy Ecological Footprint of the Export Energy Account (Unit: ghm2)

The main energy imports of Guangdong Province are crude oil, refined oil, and liquefied petroleum gas. Therefore, the foreign trade energy import account products included crude oil, refined oil, and liquefied petroleum gas, and the ecologically productive occupied land was fossil energy land. The details are shown in Figure 4.

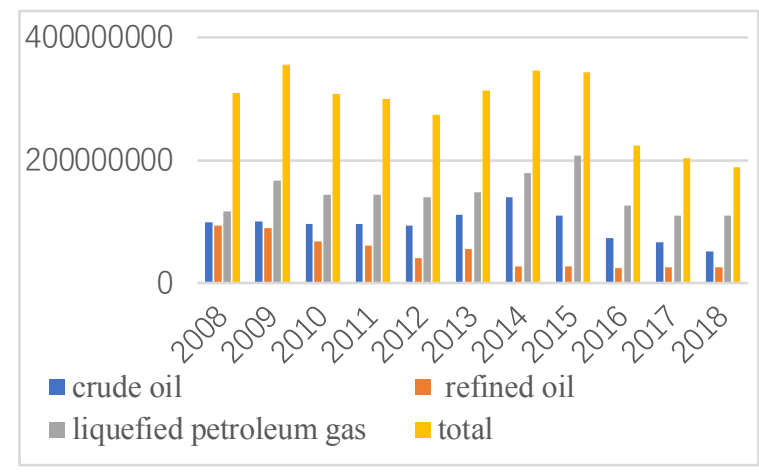

Figure 4. Emergy Ecological Footprint of the Imported Energy Account (Unit: ghm2)

\subsection{Industrial products account}

According to the import and export value, energy consumption coefficient, and inputoutput table of various industries, the ecological footprint occupied by energy consumption in the production process of the industries to which import and export commodities belong was calculated. The ecologically productive occupied land was fossil energy land.

Guangdong's industrial products foreign trade industry is classified according to the "National Industry Classification Standard2017" (UNSD:2006, International standard industrial classification of all economic activities, NEQ). Exported industrial products belong to 19 industries, and imported industrial products belong to 18 industries. According to the method mentioned above, we use the IO table-China2012 to calculate the energy consumption coefficients of different industries, and then calculate the ecological footprint of the energy consumption of the corresponding industry. Specific energy consumption coefficients of import and export industries are as follows:

Table 3: Energy consumption coefficient of import and export industries (Unit: Standard Coal/Million USD)

\begin{tabular}{lcll}
\hline \multicolumn{1}{c}{ Industries of export products } & $\begin{array}{c}\text { Unit energy } \\
\text { consumption }\end{array}$ & \multicolumn{1}{c}{ Industries of import products } & $\begin{array}{c}\text { Unit energy } \\
\text { consumption }\end{array}$ \\
\hline $\begin{array}{l}\text { 1.Electrical machinery and equipment } \\
\text { manufacturing industry }\end{array}$ & 512.1 & $\begin{array}{l}\text { 1.Electrical machinery and equipment } \\
\text { manufacturing industry }\end{array}$ & 512.1 \\
\hline 2.Textile and apparel industry & 408.91 & 3.Textile industry & 554.41 \\
\hline 3.Textile industry & 554.41 & $\begin{array}{l}\text { 5.Ferrous metal smelting and rolling processing } \\
\text { industry }\end{array}$ & 462.56 \\
\hline 4.Non-metallic mineral products industry & 1069.48 & $\begin{array}{l}\text { 6.Chemical raw materials and chemical products } \\
\text { manufacturing industry }\end{array}$ & 533.21 \\
\hline $\begin{array}{l}\text { 5.Ferrous metal smelting and rolling processing } \\
\text { industry }\end{array}$ & 462.56 & $\begin{array}{l}\text { 7.Computer, communication, and other electronic } \\
\text { equipment manufacturing industry }\end{array}$ & 353.52 \\
\hline
\end{tabular}




\begin{tabular}{|c|c|c|c|}
\hline $\begin{array}{l}\text { 6.Chemical raw materials and chemical products } \\
\text { manufacturing industry }\end{array}$ & 533.21 & $\begin{array}{l}\text { 10.Leather, fur, feathers and related products, and } \\
\text { shoe manufacturing }\end{array}$ & 412.11 \\
\hline $\begin{array}{l}\text { 7.Computer, communication, and other electronic } \\
\text { equipment manufacturing industry }\end{array}$ & 353.52 & $\begin{array}{l}\text { 11.Railways, ships, aerospace, and other } \\
\text { transportation equipment manufacturing industry }\end{array}$ & 425.3 \\
\hline 8.Furniture manufacturing industry & 384.08 & 12. General equipment manufacturing industry & 439.77 \\
\hline 9.Metal products industry & 560.35 & 15.Pharmaceutical manufacturing industry & 463.81 \\
\hline $\begin{array}{l}\text { 10.Leather, fur, feathers and related products, and } \\
\text { shoe manufacturing }\end{array}$ & 412.11 & $\begin{array}{l}\text { 17.Non-ferrous metal smelting and rolling } \\
\text { processing industry }\end{array}$ & 616.6 \\
\hline $\begin{array}{l}\text { 11.Railways, ships, aerospace, and other } \\
\text { transportation equipment manufacturing industry }\end{array}$ & 425.3 & 18.Paper and paper products industry & 817.29 \\
\hline 12. General equipment manufacturing industry & 439.77 & 19. Special equipment manufacturing industry & 447.46 \\
\hline $\begin{array}{l}\text { 13.Culture and education, aerobics, sports, and } \\
\text { entertainment goods manufacturing industry }\end{array}$ & 468.41 & 20.Rubber and plastic products industry & 427.47 \\
\hline 14.Rubber and plastic products industry & 497.48 & 21.Ferrous metal mining and dressing industry & 448.89 \\
\hline 15.Pharmaceutical manufacturing industry & 463.81 & 22. Chemical fiber manufacturing industry & 672.55 \\
\hline 16.Instrument manufacturing industry & 402.68 & $\begin{array}{l}\text { 23. Wood processing and wood, bamboo, rattan, } \\
\text { and brown and grass products industry }\end{array}$ & 498.67 \\
\hline $\begin{array}{l}\text { 17.Non-ferrous metal smelting and rolling } \\
\text { processing industry }\end{array}$ & 616.6 & 24.Automobile manufacturing & 405.84 \\
\hline 18.Paper and paper products industry & 817.29 & $\begin{array}{l}\text { 25.Printing and recording media reproduction } \\
\text { industry }\end{array}$ & 433.01 \\
\hline 19. Special equipment manufacturing industry & 447.46 & & \\
\hline
\end{tabular}

In terms of the energy consumption coefficient, the exported industry with the highest energy consumption per unit output value is nonmetallic mineral products, followed by papermaking and paper products. However, in the industrial export products account, the industries accounting for the largest amount of fossil energy land was computer communications and other electronic equipment manufacturing, followed by electrical machinery and equipment manufacturing, textiles, the clothing and apparel industry, cultural, educational, industrial, sports and entertainment products manufacturing, furniture manufacturing, and leather, fur, feathers, and their products. The analysis found that the energy consumption per unit output of the computer communication and other electronic equipment manufacturing industry was not the highest, but this industry had the highest ultimate energy consumption due to the high export volume and export amounts in recent years. As for other industries occupying more fossil energy land, they had higher energy consumption coefficients and higher export amounts. As the export value increases, the emergy ecological footprint occupied by industrial products increases. The fossil energy land occupied by the energy consumed in the production of various industries is shown in Figure 5. In the figure below, we use the serial number noted before the industry which we have marked in Table 3 to represent the corresponding industries.

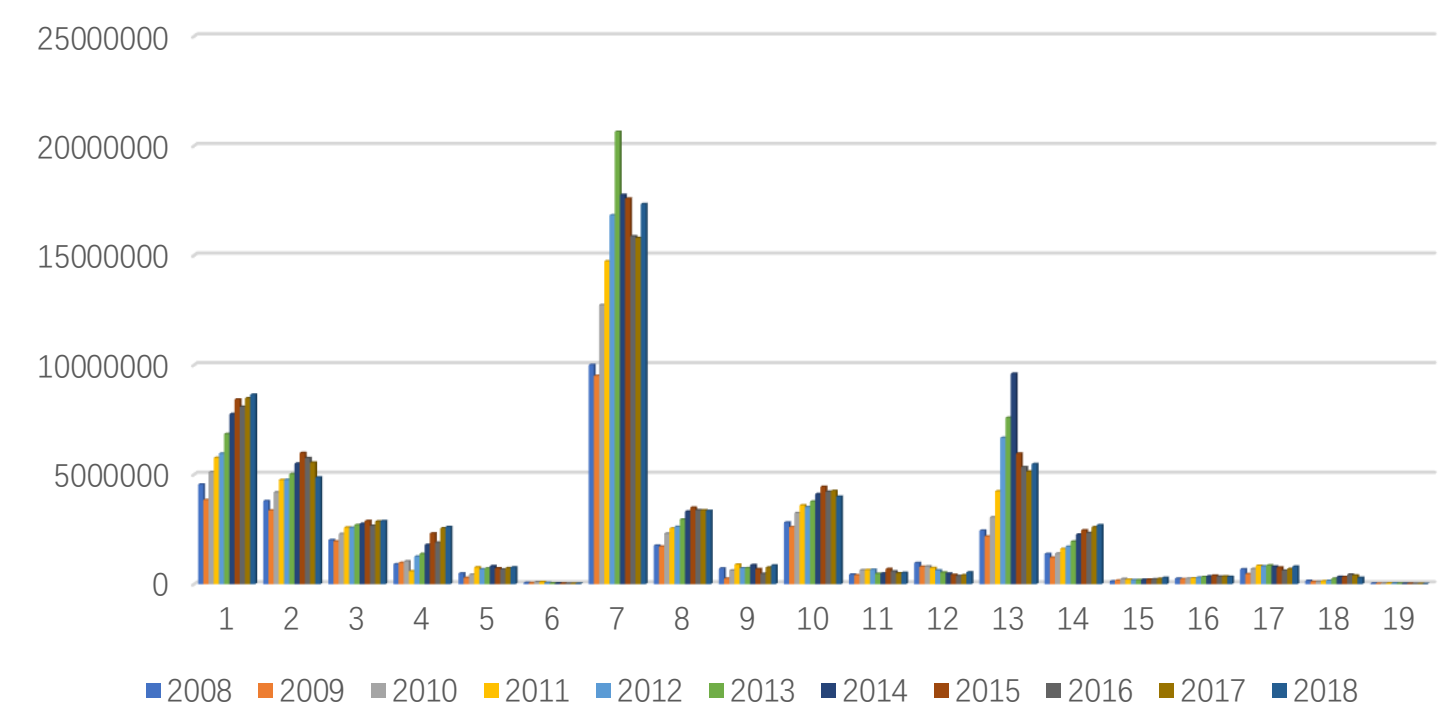

Figure 5. Emergy Ecological Footprint of Energy Consumption in the Export Industrial Products Account (Unit: ghm²) 
The imported industrial products of Guangdong Provence belong to 18 industries. Among the imported industrial products industry in Guangdong Province, the paper and paper products industry with the highest energy consumption coefficient is followed by non-ferrous metal smelting and chemical fiber manufacturing. The specific energy consumption coefficient of imported industrial products is shown in the table 3 . However, through the calculation of the ecological footprint of the energy consumption of imported industrial products, we find that the energy consumption of imported industrial products accounts for the largest area of fossil energy in Guangdong Province is the manufacturing of computers, communications and other electronic equipment. The energy consumption coefficient of this industry is not the highest, and the main reason for its largest emergy ecological footprint is due to the large amount of imports in this industry. The manufacturing of computers, communications and other electronic equipment industry's import value is the highest among all the import industries from 2008 to 2018. The fossil energy land occupied by the energy consumed in the production process of various industries is shown in Figure 6. In the figure below, we also use the serial number noted before the industry which we have marked in Table 3 to represent the corresponding industries

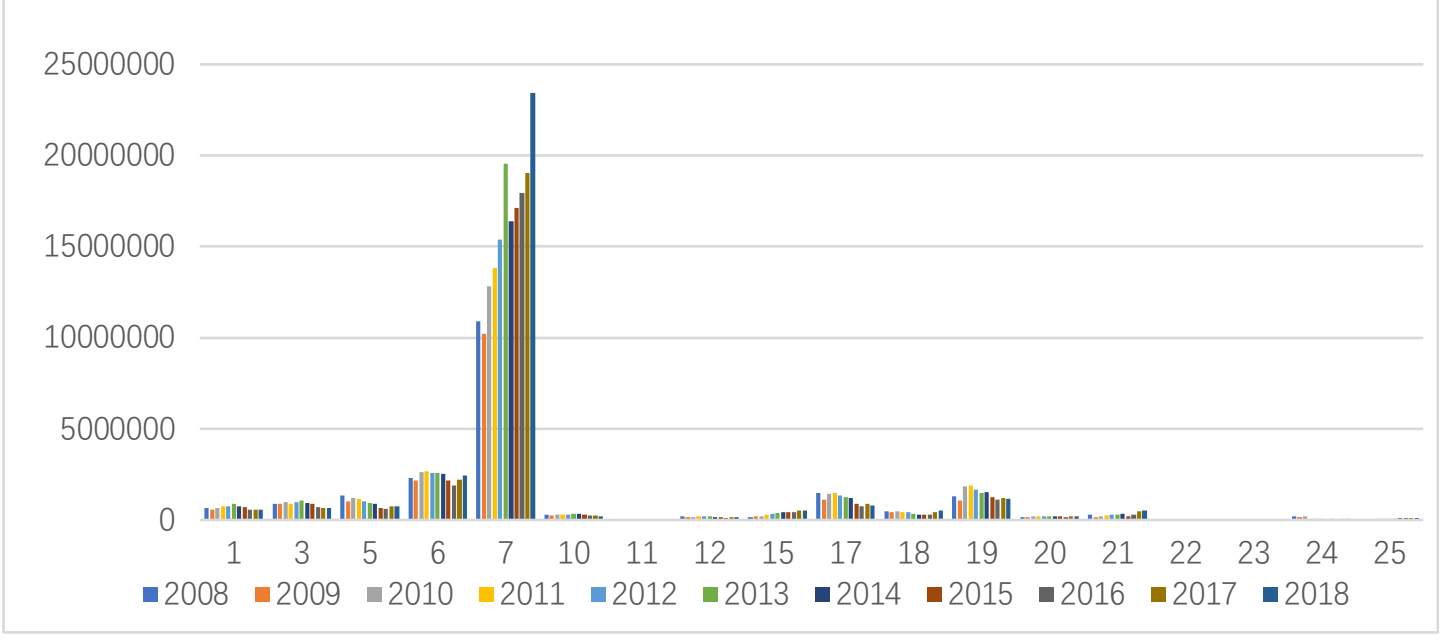

Figure 6: Emergy Ecological Footprint of Energy Consumption in the import Industrial Products Account (Unit: ghm²)

\section{Discussion}

From the perspective of the biological resources account, the comparison of the ecological footprint of imported goods and exported goods found that Guangdong Province's foreign trade from 2008 to 2018 indicated a net import of the ecological footprint in cropland and forest land and a net export of the ecological footprint in grazing land and fishing grounds. Guangdong's foreign trade resulted in the net import of ecological factors under this account. Through imports, it obtained certain ecological benefits. Judging from the trend, the net import ecological footprint of the biological resources accounts was generally on the rise. The dependence of the foreign trade of Guangdong Province on foreign natural resources has increased.

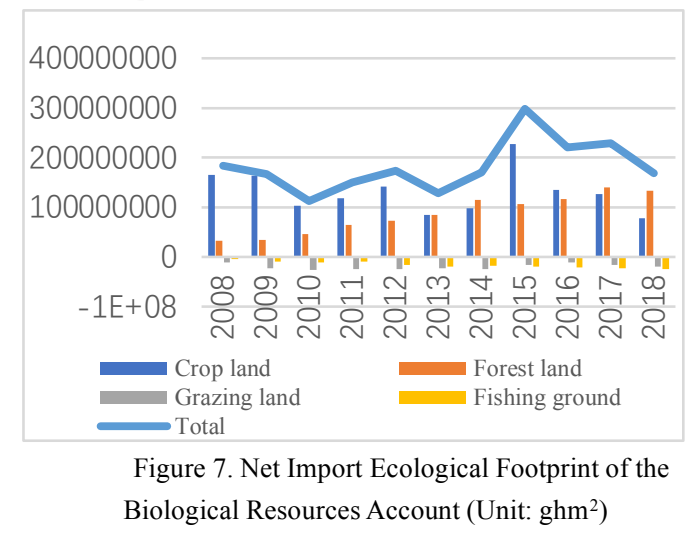

From the perspective of the energy account, the fossil energy land occupied by imported energy was much higher than the ecological footprint occupied by the export energy account. Guangdong Province's foreign trade energy account is a net importer from the perspective of ecological resources and is in a surplus of ecological benefits. Judging from the trend, the surplus of ecological benefits in the energy accounts from 2008 to 
2018 was in a shrinking state.

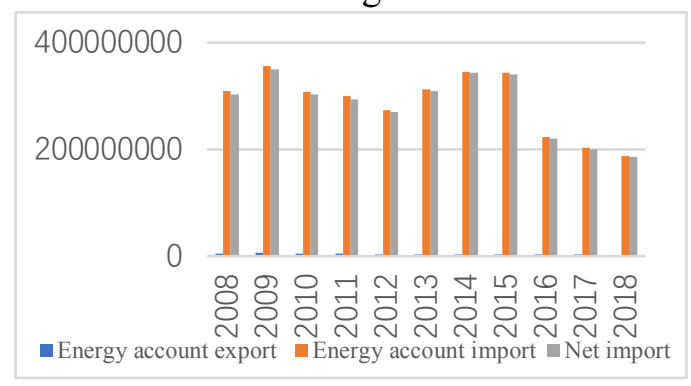

Figure 8. Net Import Ecological Footprint of the Energy Account (Unit: ghm² $^{2}$ )

From the perspective of the industrial products accounts, the fossil energy land occupied by the energy consumed by imported industrial products was lower than that occupied by the production of exported industrial products. From the ecological footprint perspective, it was a net exporter and was in a deficit of ecological interests. From 2008 to 2018 , the trade surplus of the industrial products accounts increased from 67683.12 million USD to 112242.16 million USD. The export ecological benefits of the industrial products account were not coordinated with the economic benefits. The deficit trend increased from 2008 to 2014, but decreased from 2014 to 2018.

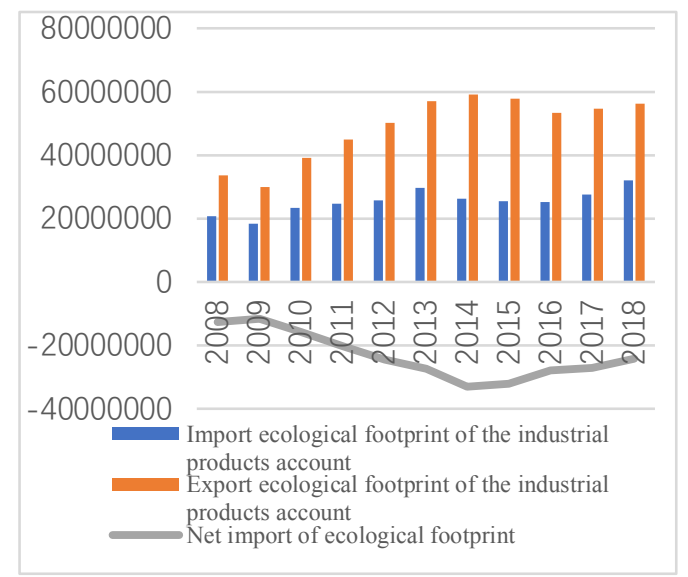

Figure 9. Net Import Ecological Footprint of the Industrial Products Account (Unit: ghm²)

To sum up, Guangdong Province's foreign trade biological resources account is in a surplus of ecological factors. Importing certain ecological factors from abroad through foreign trade is conducive to the protection of related domestic ecological resources. Specifically, crop land and forest land are the net importers of ecological footprint and are in surplus of ecological interests. Grazing land and fishing grounds are net exporters and are in a deficit of ecological benefits. Due to a large number of imported energy products, the energy account has a surplus of ecological benefits. The main reason is that the relevant domestic energies cannot meet the production needs and most energies are imported. For Guangdong Province, it is conducive to the protection and conservation of related energy resources. As the export of industrial products is the main source of foreign exchange for foreign trade, the industrial products account consumes a large amount of domestic energy in the production process, and this amount is higher than the ecological footprint occupied by imported industrial products and is in a deficit of ecological footprint. Since the export of industrial products in exchange for a large amount of foreign exchange has contributed to economic growth, and the export of industrial products has brought about the loss of domestic ecological resources, we believe that the export of industrial products in Guangdong Province is at the expense of ecological resources in exchange for economic benefits.

\section{Conclusion}

By analyzing the emergy ecological footprint of foreign trade in Guangdong Province, it could be seen that the trade mode of exporting primary products and exchanging natural resources for trade and economic benefits has been changed, and the ecological benefits of the trade of related products have been maintained to a certain extent through the import of resource products such as agricultural products and oil and gas resources products. However, the mass production and export of industrial products and the severe consumption of resources in industrial production have led to the ecological footprint of the energy consumed in the production and export of industrial products being higher than that of imported industrial products. In other words, judging from the current data, in terms of industrial trade, Guangdong's foreign trade and ecological environment are not coordinated. The coordinated development of Guangdong's foreign trade and ecological environment should start from the following aspects: (1)Strengthening the protection of crop land and grazing land in the province, the amount of related agricultural and sideline products should be increased 
moderately under the premise of meeting the safety of food and agricultural and sideline products ; (2)Purchasing wood products derived from FCS forest certification, rejecting and severely cracking down on wood products from illegal logging sources. (3)The protection of marine ecology should be strengthened, the province's advantageous geographical location and marine resources should be appropriately used to fully develop the marine economy and promote the sustainable development of aquatic product trade; (4)In order to improve the structure of energy imports and increase domestic energy utilization, corresponding measures should be taking; the further development of wind, solar, hydropower and geothermal energy, as well as the comprehensive utilization of domestic waste power generation and biogas energy will be conducive to the sustainable use of domestic energy .(5)The investment of R\&D funds in the high-tech industry should be further increased and the development of high-tech enterprises should be promoted in order to promote the further upgrading of the industrial structure; at the same time the expansion of trade of high-tech enterprises can appropriately promote the development of domestic related industries, the development of high-tech industries can reduce energy consumption and pollution in the production process, which can play a greater role in promoting sustainable development.(6)Strengthening the management of polluting enterprises, encouraging the transformation of polluting enterprises, and actively exploring new ways to deal with pollutants are also ways that are conducive to the sustainable development of trade and the ecological environment.

As Guangdong Province is a major economic province in China, when considering ecological factors in its foreign trade, we found that the economic and ecological interests of its trade are not in harmony. When other countries or regions in the world encourage foreign trade, they mostly consider it from an economic point of view, and do not consider whether the domestic ecological elements in foreign trade flow in or lose. Therefore, it is hoped that through the research of this paper, other countries or regions can consider ecological elements when actively developing foreign trade, realize the coordination of trade and ecology, and thus benefit the sustainable development of the global economy and ecological environment.
Judging from the research methods, this paper had a number of deficiencies. First, the industrial products account only calculated the ecological footprint occupied by energy consumption and did not point out the ecological footprint occupied by raw material consumption. In addition, the ecological footprint of pollutants such as wastewater, waste gas, and solid waste generated in the production of various industries was not included. For the calculation of the energy consumption of imported products, especially imported industrial products, the domestic energy consumption standard was adopted. Strictly speaking, different countries and regions show different technical levels and will have different energy consumption coefficients in the same industry. Despite the above shortcomings in the algorithm, this paper studied the emergy ecological footprint of the foreign trade of Guangdong Province, which could reflect the current ecological benefits of foreign trade obtained by Guangdong Province. Thus, this paper may serve as a reference for researchers on the overall trend and structural changes of the ecological footprint occupied by the foreign trade products of Guangdong Province. The above-mentioned deficiencies will be addressed in future studies.

\section{References}

[1]Wackernagel M Onisto L, Bello P,et al(1999). National natural capital accounting with the ecological footprint concept. Ecological Economics, 29 (3) : 375-390. [2]Odum H.T(1994)., Ecological and General Systems (Revised edition).University of Colorado Press, 15051510.

[3]Mathis Wackernagel, Chad Monfreda, Karl-Heinz Erb, Helmut Haberl, Niels B Schulz(2003). Ecological footprint time series of Austria, the Philippines, and South Korea for 1961-1999: comparing the conventional approach to an 'actual land area' approach. Land Use Policy, ,21(3).

[4]Klaus Hubacek, Stefan Giljum(2003). Applying physical input-output analysis to estimate land appropriation (ecological footprints) of international trade activities. Ecological Economics, 44(1).

[5]Daniel D. Moran, Mathis C. Wackernagel, Justin A. Kitzes, Benjamin W. Heumann, Doantam Phan,Steven H. Goldfinger(2008). Trading spaces: Calculating embodied 
Ecological Footprints in international trade using a Product Land Use Matrix (PLUM). Ecological Economics, 68(7).

[6]Kampeng Lei,Dan Hu, Zhen Wang, Yingying Yu,Yanhua Zhao(2009). An analysis of ecological footprint trade and sustainable carrying capacity of the population in Macao. International Journal of Sustainable Development \&amp; World Ecology, 16(2). [7]Elias Lazarus, David Lin, Jon Martindill, et a(2015)1. Biodiversity Loss and the Ecological Footprint of Trade.7(2):170-191. [8]ChangGeng Lu, YiChen Zhao(2013). Empirical Study on Ecological Footprint of China's Im port and Export Trade based on Emergy Theory. Mathematics in Practice and Theory.117-123.

[9]ZhaoHua Li, LingZhi Wang(2012). The Flow of Natural Capital Embodied in China's Foreign Trade and Its DeterminantsEcological Footprint Analysis Based on I-O Model. China Industrial Economics.31-43. [10]HuiPing Xia(2012). Measure and analysis of Ecological footprint of China's international trade. ZheJiang University. 26. [11]Tao-Ma, JiaKuan Chen(2005). The pollution footprint analysis of international trade of Chinese industrial products. China Environment Science. 04:508-512.

[12]ShengFang Lan, Pei Qin, HongFang Lu et al(2002). Emergy analysis of ecoeconomic system. Chemical Industry Press.11-12,17-18,75-76.

[13]ZhiQiang Zhao, JiangBo Gao,ShuangCheng Li, YangXin Wang(2009). Accounting and Analyzing Eco2economic System Using a Modified Emergy2Based Ecological Footprint Model : A Case Study in Guangdong Province(1978-2006), Acta Scientiarum Naturalium Universitatis Pekinensis, Vol. 45 , No. 5.861-867.

[14]W W Cao, C Z Sun, Improvement of the emergy ecological footprint model: A case study of Hainan. Province(2019). Acta Ecologica Sinica,39( 1) : 216-227.

[15]Fang Feng, Shuang Jin, GuiBin Dai et al(2018). Evaluation of Ecological Security in Hubei Province Based on EmergyEcological Footprint Model. Journal of Glaciology and Geocryology. 40(03):634642.

[16]WenLong Li, Wei Wei et al(2019). Sustainable Development of Tibet Based on Emergy ecological footprint Model. Acta Agrestia Sinica. 27(03):702-710.

[17]LiPing Chen, ZhiZhong Yang(2005). Ecological footprint in China's import and export trade. World Economy Studies.8-11.
[18]YanChun YU,Jing Wang(2010). Evaluation of Ecological Benefits of China's Import and Export Trade Based on Emergy Analysis. Journal of International Trade. 2028.

[19]Celil Aydin,Ömer Esen,Recai Aydin(2019). Is the ecological footprint related to the Kuznets curve a real process or rationalizing the ecological consequences of the affluence? Evidence from PSTR approach. Ecological Indicators .98.

[20]Veli Yilanci, Muhammed Sehid Gorus, Mucahit Aydin(2018). Are shocks to ecological footprint in OECD countries permanent or temporary?. Journal of Cleaner Production, 11.

[21] Andrew Adewale Alola,Festus Victor Bekun,Samuel Asumadu Sarkodie(2019). Dynamic impact of trade policy, economic growth, fertility rate, renewable and nonrenewable energy consumption on ecological footprint in Europe. Science of the Total Environment.

[22]Ali S, Yusop, Z, Kaliappan, S.R.et al(2020).Dynamic common correlated effects of trade openness, FDI, and institutional performance on environmental quality: evidence from OIC countries. Environ Sci Pollut Res27,11671-11682.

[23]Luca Di Persio, Oleksandr Honchar, Multitask machine learning for financial forecasting, International Journal of Circuits, Systems and Signal Processing, pp. 444-451, Volume 12, 2018.

\section{Acknowledgment:}

This research was support by following fund which we thanks for. And the authors would take all responsibility for this paper.

1.Department of Education of Guangdong Province. "Innovative projects with characteristics of ordinary universities" project: Research on Sustainable Development of Foreign Trade in Guangdong Province Based on Emergy Footprint.(Project. Number: 2019WTSCX158)

2.Huashang College Guangdong University of Finance \& Economics: Research on the Ecological Footprint of Foreign Trade in Guangdong Province Based on Emergy Improvement. (Project Number: 2018HSXS08)

\section{Creative Commons Attribution License 4.0 (Attribution 4.0 International, CC BY 4.0)}

This article is published under the terms of the Creative Commons Attribution License 4.0

https://creativecommons.org/licenses/by/4.0/deed.en_US 